\title{
$4 \quad$ Nonhuman Presence and Ontological Instability in Twenty-First-Century New York Fiction
}

\author{
Lieven Ameel
}

This chapter explores the appearance, in three contemporary New York novels, of ontological instability and disturbing nonhuman presence in urban space. ${ }^{1}$ Ontological instability is understood here as shifts in what is deemed as real or unreal in the storyworld and the resulting uncertainty (for characters as well as for readers) as to the stable ontological attributes of the narrated world. Such shifts feed into broader apocalyptic undercurrents in the novels discussed here. They are also important for an understanding of how fictional texts come to grips with complex environmental threats and have relevance for the relationship between human vision, consciousness, and the environment. The literary texts I will analyze are Teju Cole's Open City (2011), Jonathan Lethem's Chronic City (2009), and Ben Lerner's 10:04 (2014), novels that thematize palimpsestic layers of meaning in urban space and that are informed by an interest in the impact of imagined futures on the present. In these fictional texts, I will argue, the ontological stability of the narrated storyworld is threatened by continuous references to menacing weather conditions and by a sense of unsettling nonhuman presence.

In terms of methodological framework and theoretical approaches, my work will draw on a renewed interest in the analysis of narrative space, especially within literary urban studies (Ameel et al.; Finch et al.), and will explore ontological instability in narration from the perspective of possible world theory (Ryan, "Impossible Worlds") and Gilles Deleuze's concept (in his work on Leibniz) of the fold (Deleuze). A key question is how nonhuman presences in the urban environment, and the (visionary) perception of such occurrences, are bound up with ontological instability of the described storyworlds. I will argue that these menacing appearances are not only (or not primarily) located in spatial coordinates, but rather, that they tend to point to possible futures and to alternative possible worlds. Nonhuman presence, in these novels, tends to refer back to the unknown in temporal terms - to the threats of a possible future beyond the immediate temporal horizon.

Literary fiction has arguably had difficulties in rendering the impact of uncertain planetary futures within the formal confines of the novel (see Heise). The description of disturbing nonhuman presence-natural patterns, 
unseasonal weather conditions, and strange occurrences in the urban environment-in urban spatial environments in the novels under discussion can be seen as a particular kind of narrative strategy to render the position of human experience vis-à-vis the nonhuman and including slow-moving ecological changes. While the nonhuman intimations inhabiting urban space function on massively different, and larger, scales than the human protagonists, the sense of interconnectedness that appears from an examination of narrated space in these texts is ultimately able to convey a profound sense of entanglement between language and planetary materialities, between narrated storyworlds and the referential world.

The presences in these novels appear not only menacing to the protagonists' lives but to the very ontological attributes of the narrated storyworlds. The uncertainty as to what can be considered real or unreal, as well as the interaction between human character and nonhuman presences cannot be meaningfully unpacked with the help of dualistic approaches (pitting culture against nature, inner against outer, mind against material), but rather by approaches that allow for an integration of inner and outer. Such an approach is attempted here by drawing on Gilles Deleuze's concept of the fold.

What connects the three novels discussed here is not only that they were all written by American authors (in the case of Teju Cole, NigerianAmerican) in the early twenty-first century but also that they take place in New York City. Apocalyptic threats are a recurring feature in city literature, and New York City is a particularly conspicuous site of creative destruction (cf. Salmela and Ameel), a favored setting for catastrophic destruction in the Western cultural imagination. 9/11 looms large in the existing research on all three novels, but it will play a more minor role here. Discussing different novels that all take place in the same referential city and in the same first decade of the twenty-first century will also put into sharper contrast the wide diversity of possible worlds that may emanate from one and the same geographical referent.

\section{Ontological Instability and the Fold}

Following Brian McHale's (1987) Postmodernist Fiction, postmodern literature is seen here as primarily concerned with ontological questions (as opposed to epistemological questions in modernist literature), with ontological instability being one of the key issues at stake in postmodern literature. What is this world we find ourselves in as readers? And what is its relationship to the referential world we live in? In grappling with such questions, and in examining the relationship between a fictional storyworld and the actual world, literary scholars have tended to utilize a range of metaphors-"storyworld" itself is such a metaphor, meant to describe what takes place when a reader conceptualizes the ontological construct evoked by a literary text. Other such metaphors are the "mirror" of mimesis 
that literature is supposed to hold up to the real world; the concept of a fictional world as a separate "heterocosm" (McHale); and, more generally, possible worlds theory (Ryan, Possible Worlds). In Ryan's possible worldsbased model of narrative, such metaphors are used not only to describe the relationship between the "real" world and an "imagined," textual actual world but also that between different worlds (textual actual worlds, dream worlds, fear worlds) within the diegesis.

I propose here a different metaphorical approach to the relationships between different worlds in postmodern literature and their relationship to the actual world: that of the fold, drawing on Gilles Deleuze's reading of Leibniz (Deleuze 1988, 1993). The possibilities for applying the concept of the fold to narrative storyworlds in postmodern literature is noted in passing by Bertrand Westphal in Geocriticism (2011). Examining multiple worlds in postmodern literature, Westphal argues that "the representation of the referential world ... in fiction engages in a process of interactivity between instances of heterogeneous nature brought together in the same world through an interface ... [which] is also the means of connection between the elements of this world," and he adds that "this approach is something like the concept of the fold, developed by Leibniz in his theory of monads and taken up by Deleuze in his book on Leibniz" (Westphal 99). While Westphal does not further elaborate on this idea, the concept of the fold presents a particularly helpful metaphorization to account for ontologically problematic forms of interactions, overlaps, or distortions between different possible or actualized worlds. Not only does the fold appear as a useful concept for describing ontologically unstable worlds, it may also shed light on the way in which many of these texts are fundamentally involved in problematizing the status of the world(s) in which they take place and for questioning the chiasmus between inner and outer layers, between what is represented and what representscrucial questions in postmodern literature (cf. McHale 26-27; Westphal 88 ). Moreover, the fold also enables a way of approaching the interaction between the human protagonist and the nonhuman environment in the storyworld, an interaction which defies ready hierarchical relationships in the novels under discussion.

In Deleuze's book The Fold: Leibniz and the Baroque, the fold is a way of describing worlds that are not merely interconnected but fundamentally acting on the same plane. Conceptualizing the world in terms of the fold is to think of a fabric that, by way of the infinitely complex manners in which it is folded, connects everything material and immaterial. For Deleuze, the fold is something that examines spatial attributes-Deleuze repeatedly returns to structural elements of baroque architecture and sculpture-in a way that shows that what is thought to be outward is part of the inner, and vice versa. The whole project is, for Deleuze, as it was for Leibniz, an examination of the soul and its relation to the body, which is described in the metaphor of the spatial interior and exterior: 
The infinite fold separates, or passes between matter and the soul, the facade and the sealed room, the interior and the exterior. For the line of inflection is a virtuality ceaselessly differentiating itself: actualized in the soul it is realized in its own way in matter.

(Deleuze 242)

As a concept aimed at transgressing the distinction between interior and exterior, or superior (soul) and inferior (body), the fold as a necessary connection between two different levels provides a useful addition to the conceptual framework used for describing narrative worlds, their interrelations, and their relations to the actual world. Such relationships have long tended to be examined in terms of separations. Drawing on Benjamin Hrushovski, McHale points out that

all literary texts involve a 'double-decker' structure of reference. Literary texts project at least one internal field of reference, a universe or semantic continuum ... constructed in and by the text itself. In addition, they inevitably refer outside their internal field to an external field of reference: the objective world, the body of historical fact or scientific theory.

(McHale 28-29)

McHale draws attention to the instances in which such separations are disturbed, positing approaches such as Roman Ingarden's metaphors "iridescence" or "opalescence" and the "flickering effect" (Ingarden; McHale 32). Such metaphors, with their frame of reference of light effects and reflections, I believe, do not go far enough in problematizing more traditional notions of separation between actual and textual actual world or between textual actual and textual possible world. The fold enables a metaphorization that affords a view of simultaneously existing storyworlds that move into each other almost imperceptibly. The fold may also be helpful in conceptualizing relationships between diegetic worlds and the actual world and in describing how a literary world unfolds in the process of reading-a process that, before the age of the codex, was literally a process of unfolding (see also Caracciolo).

\section{A Commotion from an Earlier Time}

Teju Cole's Open City stands out among recent novels set in New York City for the way it reads the texture of the city in terms of simultaneously present, often threatening and overlapping layers of meaning. In Cole's novel, the protagonist Julius, a Nigerian psychiatric intern in post-9/11 New York, documents his aestheticized wanderings through the city, all the while engaging with the painful memories of the city and of his own past. The protagonist is continuously reading the space for signs of violent 
dislocations and transformations, whose lingering presences seem able to erupt in the world, as if an earlier city becomes suddenly present. In a scene early in the novel, Julius notes how one afternoon "the heart of the city was gripped by what seemed to be a commotion from an earlier time. I feared being caught up in what, it seemed to me, were draft riots" (Cole 74). ${ }^{2}$ The sense of the "heart of the city ... gripped" by an earlier commotion is one of the many examples in the novel of the "correspondence technique" (Keunen 365-66), a rhetorical trope pioneered by Charles Baudelaire by which afflictions of a narrator are transferred to the built environment (or vice versa). In this instance, it is thus arguably the protagonist himself (not the city) who is affected by a "commotion from an earlier time," and it is his privileged aestheticizing perspective which enables the reader to sense the appearance of an earlier timeframe, although the narration places the disruption as an almost tangible event in urban space.

While the superimposition of various possible layers of meaning in the process of reading the signs in the urban space could point to ontological instability (is the past really intruding in urban space?), the storyworld in Open City may well be interpreted as stable, with any folds between different temporal layers to be read as emanating from the consciousness and narration of the aestheticizing and highly self-conscious flâneurnarrator. One possible cityworld unfolds and coalesces into another on the continuous plane of the narrator's aestheticizing conscience. Such a reading would see Open City as essentially drawing on (high) modernist literary antecedents, in which, as Malcolm Bradbury noted, "one city leads to another in the distinctive aesthetic voyage into the metamorphosis of form" (Bradbury 101).

While traumatic memory and the traces of past atrocities in the present are foregrounded in the novel, Open City also displays a keen interest in intimations of the future. Fears for what the future may hold in store, informed by past layers of meaning, infuse the experience of the presence. In such instances, the protagonist takes on the role of a visionary, a Teiresiaslike character with privileged access to possible future upheavals threatening the city. An instructive scene in this respect is the description of Central Park after a torrent of rain:

The intensity of the rain blurred my sight ... The torrent had overlaid the park with a primeval feeling, as though a world-ending flood were coming on, and Manhattan looked just then like it must have in the 1920s or even, if one was far enough away from the taller buildings, much further in the past.

(Cole 36)

Different temporal levels collapse in ways that make Manhattan resemble itself as it was in earlier moments in its history-or, indeed, in its future, with the reference to "a world-ending flood." The protagonist is described 


\section{Lieven Ameel}

as having a privileged, visionary sense of future layers hidden in sight, in this case set on by a moment of temporary blindness caused by the rain. Immediately subsequently to his walk in the park, Julius ponders romantic associations between blindness and "second sight" and blindness as a "shortcut to the gifts of memory and of prophecy" (37). The same idea recurs later, in Open City's Brussels section, when another character speaks with Julius about Paul de Man's theory of blindness and insight (127; see de Man). Significantly, Julius is a reader of natural signs and described, in the beginning of the novel, as "taking auspices" like a latter day "augur" (4). Seeing two blind men on another occasion, Julius considers that his visionary senses were "under the aegis of Obatala, the demiurge charged by Olodumare with the formation of humans from clay" (25). But it is in particular nonhuman elements intruding upon the urban space, such as sudden weather phenomena or the migratory patterns of birds (e.g., 3-4) and the appearance of whales in the New York City waters (49-50), which are presented in the novel as omens of future catastrophe. The question whether the protagonist is merely imagining or correctly interpreting the meaning of such sightings is one of the ambiguities in the novel. There is a continuous obsession with the uncanny presence of natural occurrence and patterns in the city, the intimation that these may well spell a dark fate of the world, and that they are the apparitions of past or future possible versions of the present world.

Often, it is not so much a presence that points to future threats but rather the appearance of absences of what would be expected to be present. This play on simultaneous presence and absence is one way in which Open City undermines its storyworld's ontological stability. It is possible to postulate, in the background of such experiences, the experience of the "absent presence" or "present absence" of the twin towers in the wake of 9/11 (see Ameel "Reading Signs"). But the experience of absence can also be seen as looking forward to the theme of mourning future losses, which has become one of the themes of climate change fiction (what has been called proleptic mourning; see Garrard). Repeatedly, disturbing absences in Open City point to weather conditions in the city:

The absence of this order, the absence of cold when it ought to be cold, was something I now sensed as a sudden discomfort. The idea that the weather was changing noticeably bothered me.

(Cole 28)

The unseasonability of the weather is an indication that all is not right-not with the protagonist, who, as it turns out, is running away from his own past guilt; and not with the city, which appears to be reliving its own traumatic pasts time and again and in which the weather and partly inexplicable animal patterns point to possible future disaster. In Open City, a recognizable New York City is stratified with past, possible, and future layers of 
meaning, of which weather conditions and natural patterns seem to be the harbingers. Echoing Deleuze's thinking on the fold, such different layers (for example, past draft riots as resonating with early twenty-first-century New York City demonstrations) are presented as simultaneously present, as in the folding of different temporal planes of meaning. There is a strong sense of the inner and outer world colliding, and of a correspondence between the protagonist's inner world and the urban environment, for example when Julius senses "the commotion" at the "heart of the city."

\section{Two Temporalities Collapsed into a Single Image}

In Ben Lerner's 10:04 (2014), the reader again meets unseasonable weather, strange omens, and the visionary capacities of an aestheticizing narrator walking a New York City that appears both recognizable and yet a defamiliarized version of its referential self. The "unseasonable warmth" is noted in the first sentence (3), and further mentions to the warming planet (7-8) and the weather's unseasonability are repeated throughout the novel $(32,107)$. To the narrator, a keen walker and aestheticizing figure like the protagonist in Open City, the appearance of an out-of-place heat (in the following passage re-written in a third person novel-within-the-novel), is reminiscent of a photographic visual effect:

The unusual heat felt summery, but the light was distinctly autumnal, and the confusion of seasons was reflected in the clothing around them. ... It reminded him of a doubly exposed photograph or a matting effect in film: two temporalities collapsed into a single image.

(Lerner 63)

In 10:04, unusual climatological circumstances take center stage. But the effect of out-of-time conditions is not described in terms of unusual weather replacing that of earlier times but with an image from photography, as the co-existence of two different temporalities- "two temporalities collapsed into a single image." ${ }^{3}$

Centered on the experience of Hurricanes Sandy and Irene, the plot of 10:04 deals with how the city and its inhabitants cope with the threat and then impact of life-threatening storms. But the issue of changing, threatening weather conditions and the intimation of out-of-place presences in the urban space also points to the overlapping folds of simultaneously present storyworlds: the blurring or fading of a world as we know it. The tangible presence of possible futures and different pasts is described as encroaching on the ontological stability of the present. 10:04 takes a cue from the 1985 movie Back to the Future, in which the protagonist Marty, traveling in time, disturbs the meeting between his own father and mother, thus potentially erasing his present self $(9-10,52)$. The title 10:04 is a reference to the moment when lightning strikes the clock tower in the movie, enabling 


\section{Lieven Ameel}

Marty to return to his own time. The playful reference is re-enacted on the mundane level of the protagonist's personal life: while waiting with his close friend Alex in her apartment for a once-in-a-generation storm to strike New York, the two have a moment of intimacy. But when the storm, whose anticipation triggered their intimacy, does not materialize, their experience feels to have passed into the unreal:

[It] was as though the physical intimacy with Alex, just like the sociability with strangers or the aura around objects, wasn't just over, but retrospectively erased. Because those moments had been enabled by a future that had never arrived, they could not be remembered from this future that, at and as the present, had obtained; they'd faded from the photograph.

While the experience is personal and mundane, the consequences of the unrealized natural occurrence are felt within the storyworld beyond the personal sphere, affecting also the memory of the communal experience ("the sociability with strangers") in expectation of the storm, as well as the "aura around objects." The ontological status of the world is impacted by the way the future is imagined, and when such imagined futures are transformed, so are the characteristics of the present. 10:04 constantly plays on the effect, not only of natural occurrences and presences but also on that of absences. The present is determined by how past and future layers of meaning-or their absence-are narratively folded into the present, lending the present and lived storyworld distinctly unstable and unreal characteristics.

The unseasonable weather strongly feeds into broader world-threatening strands of the novel. The protagonist lives in anticipation of apocalypse, and the sense of impending doom in the novel is continuously reinforced by the protagonist's reading of incongruous presences, such as the "ominous medium" of "tropical humidity that wasn't native to New York" (18). $\mathrm{He}$ is described as someone who imagines "the global apocalyptically" (14), as taking mundane decisions in his life "because ... the city would soon be underwater" (153), and imagining a "not-so-distant future where New York was largely submerged" (132). This imagined disastrous future strongly informs his readings of the present, as when he imagines that the water damage to paintings is the result of the coming catastrophic flood (132). All this is bound up with the protagonist's distorted or hypersensitive senses, especially his vision. Early in the novel, with the city bracing for the coming storm, the protagonist is struck by how things have taken on a new "radiance," only to realize "the alteration was most likely in my vision" (18).

The foregrounding of vision is a reminder that the instability of the storyworld is located in the narrator, whose senses and cognitive capacities are presented as idiosyncratic and untrustworthy. In the opening pages, he 
intuits within himself " an alien intelligence ... and affects that did not, properly speaking, belong to me" (3)-a possible reference to the residue of the baby octopus he eats alive just moments before (see also De Bruyn 963). The reader learns to further distrust the narrator when it becomes clear that he has a heart condition that affects his cognitive capacities. Fearing an upcoming medical test, he notices he is affected by psychosomatic "[headaches], disordered speech, weakness, visual disturbances, nausea, numbness, paralysis ... The momentary sense of having traveled back in time" (74). The awareness of unseasonable weather could be attributed to a confusion of the senses, as when the narrator realizes that the sensation of a "false spring ... might have been a mild olfactory hallucination triggered by memory—or, I found myself thinking, a brain tumor" (108). The simultaneous co-existence of remainders of earlier times or forebodings of future times in the present is thus suggested to emanate from the narrator's disturbed consciousness and senses. The "doubly exposed photograph," in which "two temporalities [are] collapsed into a single image" (63), it is suggested, does not exist other than in the imagination (or the delusion) of the onlooker. And yet it would go too far to argue that the many nonhuman layers of meaning the protagonist senses have no anchoring in the actual storyworld. Rather than the one causing the other, they are constituted on the same plane, in the manner of Deleuze's fold. In describing the relationship between consciousness and the threatening urban environment as an intertwinement, not a causal linkage, Ben Lerner inscribes himself in a recent literary paradigm that Heather Houser has described as "ecosickness." Ecosickness is a literature in which "humans and the more-than-human world do not only interact but, more importantly, are coconstitutive. This literature shows the conceptual and material dissolutions of the body-environment boundary through sickness and thus alters environmental perception and politics" (3). In 10:04, the nausea and sensory disturbances of the protagonist are coeval (a word with special resonance for Lerner and 10:04 in particular; Lerner 66-67, 71) with environmental disturbances in a way that resonates with past and future events and defies clear linear or causal relationships. While this impression of resonating with the environment is clearly informed by somatic and psychosomatic disturbances in the protagonist, there is also a sense of the narrator as a privileged visionary: the idea that it is exactly his condition and the "visual disturbance" he experiences that help him to feel with his environment.

In the notion of the early twentieth-century sociologist Robert Park, the city is a "mosaic of little worlds that touch but do not interpenetrate" (608). Similarly, Timothy Morton, when reflecting on the fragile and contingent nature of cities in Dark Ecology, states that "[places] contain multitudes" (12). It is in the visionary, aestheticizing consciousness of a narrator such as Lerner's that these multiple worlds can for a moment coexist, together with a variety of past and future presences-including that of the reader. Walking in the shadow of the "felt absence of the twin 
towers" (237) and in the shadow of another "historic storm that had failed to arrive" (231), Lerner's narrator enables a range of worlds to coexist for a brief moment and draws a comparison with the New York City cabs which, for this short crisis moment, accept multiple fares, "fares from multiple worlds" (237).

The presence of temporally uncoupled layers of meaning also draws on an aestheticizing and intertextual play on other literary cities. This becomes explicitly spelled out in one of the culminating scenes of the novel, when Ben and Alex walk through lower Manhattan and across Brooklyn Bridge, with the narrator imagining "all of us were dead, flowing over London Bridge" (239). The reference to T.S. Eliot's The Waste Land, with its reverberations of Dante's Divina Commedia (in a 10:04 passage already heavily, and explicitly, indebted to Walt Whitman's poetry), opens up the text to a complex interplay of meanings, driven by intertextual references activated in the reader and folding into the narrator's collapse of past and futures presences in the singular moment. 10:04 has also been read, recently, in terms of its continuations of a realist mode (De Bruyn), but references such as these gesture, rather, to a continuation of the aestheticizing and associative mode of high modernism. The result is an "unreal city"-but in ways that are different from Baudelaire's Les Fleurs du mal (the original reference of "unreal city") and Eliot's The Waste Land: the narrator is not merely invoking a literary trope when suggesting, as Baudelaire does in Le Spleen de Paris, "that all these things think through me, or I think through them" (Baudelaire 4). In 10:04, the narrator describes how he feels his "senses and the city vibrating at one frequency" (28), but he is also hinting at the planetary dimension of such correspondence, in the references to the affinity between narrator and octopus (3); in his hypersensitive awareness "that water surrounded the city, and that the water moved" (28), and the intuition of planetary warming (7).

More radically, it is not only potential futures and past readings of other cities that are folded within the present storyworld, but also the physical world of the reader. Following the reference to London Bridge, the narrator continues the description of the communal spectacle of people gathered on Brooklyn Bridge in the dark, describing how the "fireworks celebrating the completion of the bridge exploded above us in 1883, spidering out across the page" (239), inviting the reader to contemplate the material texture of the page she holds. For a brief moment, the canvas of the night sky and the page of the book held by the reader coexist, in a metaleptic operation that is also at work in use of photographs on the page and in the occasional address to the reader with a compelling you (see Gibbons). Here the novel attains, by folding multiple planes simultaneously, what the baroque fold had endeavored: to break down the boundaries between the worlds of spectator and artwork, while simultaneously giving the onlooker a glimpse of how the artwork relates to a cosmic (or, in Lerner's case, planetary) scale. 


\section{Ellipses, Hiccups, and Pocket Universes}

In Jonathan Lethem's Chronic City (2009), intimations of nonhuman presences and absences in urban space are taken to a new level of threat and uncertainty. The New York City of Lethem's novel is clearly not to be mistaken for the referential New York in the early twenty-first century. To begin with, the basic information the reader receives does not match with the real-world city on the East Coast of the US: the mayor is called Jules Arnheim, the twin towers are still standing, and Russia and the United States are allied in a space war conflict with China. Moreover, there are a range of nonhuman presences, bordering on the fantastic, that demand the reader's attention: a mysterious "fog" that has settled on lower Manhattan (13); a giant tiger (itself with unclear ontological status, since it is rumored to be a tunnel digging device on the loose [163]) is slowly destroying the underground (35-36); gigantic chasms are opening up in the city as part of radical conceptual art work. Several characters share a preoccupation with strange animal movement in the city: a sub-plot involves the habits of a pair of eagles; a "minke whale, its motives perhaps deranged by ocean fungus," has become stranded near New York's Hell Gate and died (68); and the protagonist is repeatedly described as fascinated by the patterns of flight of the birds around the tower he sees from his window (e.g., 125-26; 465-66). While Open City and 10:04 draw heavily on the aestheticizing tendencies of modernist city writing, in which an oversensitive consciousness reads mythical meanings into the everyday and in which ontological uncertainties can still arguably be attributed to an aestheticizing (and unreliable) narrator, Chronic City moves closer to the ontological instability described in McHale's Postmodernist Fiction (1987). If Chronic City differs from 10:04 and Open City in how it locates ontological instability more firmly outside of the narrator's consciousness, this is also in part because the reader comes to know New York City through multiple perspectives and by way of the protagonist's-Chase Insteadman's-friend Perkus Tooth, who acts as Chase's guide to the many hidden and often contradictory layers of the city. The novel begins when Chase meets Perkus, a socially awkward castout with a tendency for drawn-out conspiracy theories. In lieu of a plot, the novel presents a series of events which see Chase navigate the labyrinthine city in a journey that increasingly resembles a quest to distinguish the real from the illusory. Perkus's point of view gradually becomes the protagonist's - and thus the reader's "door to my life in the city as I knew it now" (404). The dependence on the perspective of Perkus foregrounds again the importance of (erratic) vision for constructing knowledge of the world. He has a lazy, "deviant" eye (16) and a "double and wandering vision" (262). Chase is described as gradually becoming initiated into this mode of seeing, and describes himself as having become "an acolyte to his brand of ... vision” (262). 


\section{Lieven Ameel}

More radical than a mere lazy eye, Perkus is beset by conditions described as "ellipsistic," in which time and space appear as ellipses, expanding uncontrollably $(26 ; 45)$ : a "species of blank interval, a nod or fugue in which he was ... [merely] between" (3). Throughout the novel, there is a strong suggestion that this disturbing vision enables access to crucial and otherwise inaccessible information: Perkus notes that ellipsis "is like a window opening” (27). Intriguingly, Perkus speaks of such visionary information in terms of seeing an animal: the "blot" on his vision during one "ellipsistic" seizure was like "an elephant in my apartment ... crowding to the edges of the room" (83). Of course, the "elephant in the room" is a figure of speech. But the elephant is here, for Perkus, to be taken almost literally: "I felt like I could stroke its pebbly hide" (83). In this elliptic mode, it is suggested, metaphorical utterances may be taken literally, and the figural becomes accessible as a tangible material reality. Throughout the novel it is asserted-similarly to Open City and 10:04-that a disturbed or impaired vision may enable one to gain access to privileged knowledge. Perkus notes that "[most] of his proudest writing ... was born of some glimpse of ellipsistic knowledge" (26). Crucial features of the environment in Chronic City tend to appear at the edges of vision-Major Arnheim, the center of power in the city, is described by Chase as "almost impossible to regard directly, like a black hole or a blot on my vision" (280).

The focus on vision and on the importance of glimpses of other worlds lurking at the edge of vision takes on two important aspects. The first one is that of the frame. Perkus Tooth insists that "[that] glimpse is intolerable. When your gaze slips beyond the edge of a book or magazine, you notice the ostensible texture of everyday reality" $(79) .{ }^{4}$ There is the suggestion that the "texture of everyday reality" is hidden just out of sight or at the edge of sight-a world to be discovered if only we could look more clearly from the corner of the eye. An echo of such a vision is found also in Morton's Dark Ecology, which argues that

[nearness] does not mean obviousness ... When massive entities such as the human species and global warming become thinkable, they grow near. They are so massively distributed we can't directly grasp them empirically. We vaguely sense them out of the corner of our eye while seeing the data in the center of our vision.

What is seen from the corner of the eye in Chronic City's Manhattan is not a single, coherent world but multiple spaces folded into spaces,

worlds squirreled inside one another, the chaotic intricacy with which realms interleave, like those lines of television cable and fresh water and steam heat and outgoing sewage and telephone wire and whatever else which cohabit in the same intestinal holes that pavement-demolishing 
workmen periodically wrench open to the daylight and to our passing, disturbed glances.

This observation of spaces enfolded in spaces, "worlds squirreled inside one another" is repeated throughout the novel. Perkus has the capacity to glimpse "bonus dimensions, worlds inside the world" (27). And the super-rich Woodrows' concealed home, a "house within-a-building," has an elaborate entrance that (to the narrator) seems to tell the neighbors that "your indoors is our outdoors" (28; italics in the original)-thus announcing, like the baroque fold, "that the inside is nothing more than a fold of the outside" (O'Sullivan 107).

What is hovering at the eye is thus not a singular, stable reality but the existence of numerous worlds. As Oona, Chase's love interest in the novel, imagines: "we're just one of innumerable universes living in parallel" (197), reminding one of Leibniz's theory of monadology, with its multiple worlds, from which the concept of the fold developed. The image of "innumerable universes" is no mere metaphor from Oona but an endeavor to access accurately the ontological status of the world they live in, because Oona and Perkus are considering the odds that they are living in a computer simulation (a view of the world popularized by, amongst others, the 1999 movie The Matrix, and which has more recently gained a more serious following in Silicon Valley circles; see Solon 2016). Perkus's and Oona's fantasies of multiple computer simulations are variations on a more mundane theme: that of individual humans as single, self-centered worlds (the novel uses for this the term "demimonde," literally half-world), with limited access to other worlds. Perkus insists that "no body ... really believes in the news from beyond the boundaries of their neighborhood or pocket universe. Manhattan is one of those, you know, a pocket universe" (328; original emphasis). It is a position that enables people to be blind to others' realities, or amnesiac-a position Perkus criticizes Chase for and which he deems typically American (in a statement that could easily be read as both a reference to the memory of $9 / 11$ and the international repercussions of the subsequent war on terror): "You're like the ultimate amnesiac American, Chase. You never can imagine anything actually happened before you wandered along" (207).

If the emphasis on glimpses of alternative realities and problems caused by visionary blots accentuate the inaccessibility of reality, there is also a pull in another direction: if vision is so central to our relation with reality, the reality of the world is perhaps determined by how one sees, rather than the other way round. Did the world exist before some cognitive being "wandered along"? This position comes close to idealism, a philosophical movement associated amongst others with Bishop Berkeley, whose thinking in this respect is conventionally summed up in the argument "esse est percipi (aut percipere)"- to be is to be perceived (or perceive) (Downing). It is a 
position repeatedly hinted at in Chronic City. Perkus argues that such an idealist view, in which matter is conceived as not existing unless observed, may be an ontological prerequisite for the world in which they live (if it is, indeed, as he and Oona consider, a computer simulation world), because it would, within multiple computer simulations, take too much energy "to make everything exist whether we look at it or not" (229; original italics).

Not only are the ontological bearings of the world determined by how one sees, but there are also suggestions that the world functions according to the words coined to describe it. It is a narrative strategy common in postmodern literature and used to great effect in the work of Thomas Pynchon- "the literalization of a situation initially implied as metaphorical" (Simonetti 57). One example of such literalization is the description in Chronic City of "money men ... slumping through the gray fog" (30), and lower Manhattan under a "cloud bank" (201)—a condition that turns out to be not figurative but literal (and open, of course, to interpretation as allegory for 9/11). Words seem to have power over the world, and this goes most obviously for Chase himself, who turns out to be living a script written by Oona and produced for the entertainment of the city. There's also the suggestion, for example, that the New York Times "is getting its material" from a drug dealer's invented marihuana brand names, rather than the more obvious reverse interpretation (187). Such complications between the world and words also invite the reader to reconsider her own world and the extent to which it is constructed according to narrative frames.

The relationship between human observer/narrator and the nonhuman environment (including strange weather, disturbing natural occurrences, animal patterns) oscillates in Chronic City between two positions on how human language and vision interact with the nonhuman world: on the one hand, the idealist conceptualization that the world (in its very ontological existence) is dependent on conscious vision; on the other hand, a much more skeptical idea of reality as a collection of (potentially infinite) worlds that can be accessed only with difficulty and through compromised senses. It's an oscillation that has antecedents also in nineteenth century literature's preoccupation with modes of seeing as knowledge and deception (Goulet), in Baudelaire's correspondences, and before that the romantic mode's searching relationship with the environment, which incorporated monist tendencies (see De Man 187-228). Chronic City presents a conglomerate of worlds in which nonhuman occurrences (such as the fog in southern Manhattan) affect the senses (vision, smell), and animal patterns force inhabitants out of their homes (the pair of eagles, the tiger). On the other hand, the novel also presents an environment where words used to denote that very world may affect its ontological attributes. When Perkus claims that "[something] happened, Chase, there was rupture in this city. Since then, time's been fragmented" (389), the hiccups in the soliloquy can be seen to correspond to the holes being torn in New York, but raise the question whether there is a causal relationship between the gaps in speech 
and gaps in space-and in what direction that relationship moves? It is noteworthy that the hiccups are presented as a natural force, since Perkus contracted them from his dog. This much is certain: that the hiccups appear as real gaps in the textual matter on the page.

What in both interpretations remains is a sense of radical interconnectedness. And similar to Ben in 10:04 and Julius in Open City, it is the protagonist's privilege to move through these multifarious worlds and to provide a connection point. In what he calls "another wave of my straddling-universes feeling," Chase feels he is the link between otherwise unconnected worlds (in this specific case, those of Perkus and the conceptual artist Noteless): "Only I had the freedom to dabble in each of their realities and feel the native absurdity of their simultaneous distance and proximity" (229-30). Chase himself is, in his quest for reality, enacting the operations of the fold-moving between "the façade and the closed room, the outside and the inside" (Deleuze 39). Making sense of the numerous worlds to which he is introduced by Perkus is described literally as a folding operation, Chase's "attempt to collate and refold his many crumpled maps of the universe" (404), the result of which is the narration presented in Chronic City.

\section{Conclusion}

In Open City, 10:04, and Chronic City, natural patterns, unseasonal weather conditions, and strange occurrences in the urban environment are bound up within a larger frame of reference that emphasizes as well as questions human vision and memory and that carries intimations of possible worldthreatening scenarios. In all three novels, apocalyptic strains can be read through the lens of 9/11, as mediations on remembrance and trauma and as endeavors to give past traumatic experiences a meaningful place in the present (see, e.g., O'Gorman, Severs). But there are other things at stakethe emphasis in all three novels on strange weather patterns, on experiences of visionary correspondences with the environment, and on the shadow cast by uncertain futures also feeds into narratives of climate change and into contemporary preoccupations with ontological questions.

In Open City and Chronic City, the way in which nonhuman presences, as well as past and future temporal layers, are imbued with meaning can arguably be located in the aestheticizing tendencies of the narrators. But there is also a sense that the visionary narrators are able to feel with the environment, rather than being sovereign attributors of meaning. Both texts can be approached as forms of "Ecosickness," a literature in which the human and the nonhuman appear as coconstitutive (Houser); especially so in the case of 10:04. In Chronic City, ontological instability is further multiplied, and the world is represented as open to a range of different explanationsmoving from extreme forms of idealism to skepticism as to the possibility of experiencing anything beyond one's immediate "demimonde" or "pocket universe.” 
The overlap between various (possible mutually exclusive) storyworlds and temporal layers in these three novels-although realized in different degrees and by using different narrative strategies-cannot be meaningfully unpacked by looking at the narrated ontological instability in terms of worlds "flickering" (Ingarden), or as "Swiss Cheese," in which the "irrational is contained in delimited areas that pierce the texture of the fictional world" (Ryan 377), or by positing heterotopian zones (McHale 43 ff.). ${ }^{5}$ Rather, it proceeds by way of folds, similar to paper or cloth folding and unfolding: the present of past trauma and future possibility coexisting in a raindrenched Central Park in Open City; temporal layers superimposed like "a doubly exposed photograph" in 10:04; worlds "squirreled inside one another" in Chronic City, with the narrator left to "collate and refold" the various maps.

Human consciousness, and its ability to connect with the world, is at once "blind" and, paradoxically, capable of visionary "insight," as the protagonist of Open City, drawing on Paul de Man, infers. The visionary experiences of Ben, in 10:04, driven by something close to hallucination, and the insights provided by "blots on vision" and by looking out of the corner of one's eye in Chronic City, point to a similar flawed yet insightful sensitivity, in a way that defies binary oppositions or causal hierarchies. The real, the possible, and the imaginary are described as continuations of the same plane, coeval with human perception. In 10:04 and Chronic City, in particular, there are endeavors to extend that folding of inner and outer into the world of the reader, such as the hiccups of Perkus in Chronic City, visualized on the page in blank spaces and the fireworks above Brooklyn Bridge, in 10:04, which are imagined on the physical page in the hands of the reader, thus extending tangibly into the reader's physical world.

Approaching ontological instability and the interaction between human perception and nonhuman environment through the concept of the fold helps home in on those elements that spill out from the fictional representation into the actual world. Such spill-over effects re-enact the Baroque breaking of spatial boundaries; Deleuze was intrigued, following Wölfflin, in how Baroque form was "always put in motion" ending "in the manner of a horse's mane or the foam of a wave," and how "matter tends to spill over in space" (4). The endeavors to reach out into the reader's referential world, evident especially in Chronic City and 10:04, are one particularly tangible example of such overspill. In language, a tentative overlap between the consciousness of reader and narrator is attempted, a moment of "coeval readership" (Lerner 93). Similar to Perkus's view of New York City, which becomes for Chase an "ellipsistic" experience that starts to affect his own perception of the surrounding world, some of the visionary experiences in these novels may color the reader's view of the referential world, enabling a sense of interconnection with the nonhuman environment, in the way of a fold connecting inner and outer, actual and possible. 


\section{Notes}

1 A shorter and amended version of this article appeared in Style 55 no. 3 under the title "Ontological Instability and Nonhuman Presence in Twenty-First-Century New York Fiction."

2 The draft riots of 1863, in which underprivileged New Yorkers-many often only recently arrived in America-revolted against being drafted into the Union Army and targeted the authorities as well as African Americans. The reference feeds into Open City's overall examination of the theme of migration, violence, and uneasy racial relationships.

3 Brian McHale mentions "double vision" in his treatment of postmodernist fiction and the zone, but rather than retaining this idea of the simultaneity of two different temporal levels, when discussing Elkin's George Mills and Pynchon's Gravity's Rainbow, he returns to metaphorizations that suggest the separation of different levels, moving from "double vision" to "split-screen effect" to different temporalities that "flicker back and forth" (93).

4 For more on the importance of the concept of "frame" in the work of Lethem, and its links to the work of Heidegger, see O'Gorman 45-47.

5 It could be argued that Lethem's Chronic City does refer to McHale's concept of the zone explicitly and repeatedly (e.g., 107, 174, 382) - and yet these zones (sometimes with zone between quotation marks; 243) never appear as radically set apart from the rest of the narrated world but rather as overlapping, or folding in, with other, less defamiliarized spatial environments.

\section{References}

Ameel, Lieven, Jason Finch, and Markku Salmela. Literature and the Peripheral City. Palgrave, 2015.

Ameel, Lieven. "Open City: Reading Signs of Uncertain Times in New York and Brussels." Mielikuvituksen maailmat/Fantasins världar/Worlds of Imagination, edited by Merja Polvinen, Maria Salenius, and Howard Sklar, Eetos, 2017, pp. 290-308.

Bradbury, Malcolm. "The Cities of Modernism." Modernism, edited by Malcolm Bradbury and James McFarlane, Penguin, 1976/1986, pp. 96-104.

Baudelaire, Charles. The Parisian Prowler: Le Spleen de Paris, Petits Poèmes en Prose. Translated by Edward K. Kaplan, University of Georgia Press, 1869/1989.

Caracciolo, Marco. "Ungrounding Fictional Worlds: An Enactivist Perspective on the 'Worldlikeness' of Fiction." Possible Worlds Theory and Contemporary Narratology, edited by Alice Bell and Marie-Laure Ryan, University of Nebraska Press, 2019, pp. 113-131.

Cole, Teju. Open City. Faber and Faber, 2011.

De Bruyn, Ben. "Realism $4^{\circ}$ : Objects, Weather and Infrastructure in Ben Lerner's 10:04.” Textual Practice, vol. 31, no. 5, 2017, pp. 951-971.

De Man, Paul. Blindness and Insight: Essays in the Rhetoric of Contemporary Criticism. University of Minnesota Press, 1983.

Deleuze, Gilles. Le pli: Leibniz et le baroque. Éditions de Minuit, 1988.

Deleuze, Gilles. The Fold: Leibniz and the Baroque. Translated by Tom Conley and Athlone Press, 1993.

Downing, Lisa. "George Berkeley." The Stanford Encyclopedia of Philosophy, edited by Edward N. Zalta, 2013, https://plato.stanford.edu/archives/spr2013/ entries/berkeley/. 
Finch, Jason, Lieven Ameel, and Markku Salmela, editors. Literary Second Cities. Palgrave, 2017.

Garrard, Greg, "Climate Change and the Art of Memory." thememorynetwork.net, 18 March 2014, http://thememorynetwork.net/climate-change-and-the-art-of-me mory-greg-garrard/.

Goulet, Andrea. Optiques: The Science of the Eye and the Birth of Modern French Fiction. University of Pennsylvania Press, 2006.

Gibbons, Alison. “Autonarration, I, and Odd Address in Ben Lerner's Autofictional Novel 10:04." Pronouns in Literature: Positions and Perspectives in Language, edited by Alison Gibbons and Andrea Macrae, Palgrave, 2018, pp. 75-96.

Heise, Ursula. Imagining Extinction. University of Chicago Press, 2016.

Ingarden, Roman. The Literary Work of Art: An Investigation on the Borderlines of Ontology, Logic, and Theory of Literature. Northwestern University Press, 1980.

Keunen, Bart. "The Decline of the City as Modernist Symbol: City Images in Postmodern Urban Fiction and in Collective Memory." The Urban Condition: Space, Community and Self in the Contemporary Metropolis, edited by Dirk De Meyer et al., 010 Publishers, 1999, pp. 359-376.

Lerner, Ben. 10:04. Faber and Faber, 2014.

McHale, Brian. Postmodernist Fiction. Routledge, 1987/2003.

Morton, Timothy. Dark Ecology: For a Logic of Future Coexistence. Columbia University Press, 2016.

O'Gorman, Daniel. Fictions of the War on Terror: Difference and the Transnational 9/11 Novel. Palgrave, 2016.

O'Sullivan, Simon. "Fold." The Deleuze Dictionary: Revised Edition, edited by Adrian Parr, Edinburgh University Press, pp. 107-108.

Park, Robert E. "The City: Suggestions for the Investigation of Human Behavior in the City Environment." The American Journal of Sociology, vol. 20, no. 5, 1915, pp. 577-612.

Ryan, Marie-Laure. Possible Worlds, Artificial Intelligence, and Narrative Theory. Indiana University Press, 1992.

Ryan, Marie-Laure. "Impossible Worlds." The Routledge Companion to Experimental Literature, edited by Joey Bray, Alison Gibbons, and Brian McHale, Routledge, 2012, pp. 368-379.

Salmela, Markku and Lieven Ameel. "New York Fiction.” Palgrave Handbook of Literature and the City, edited by Jeremy Tambling, Palgrave, 2016, pp. 317-332.

Severs, Jeffrey. "Memorializing Post-9/11 New York in Jonathan Lethem's Chronic City." Representing 9/11: Trauma, Ideology, and Nationalism in Literature, Film, and Television, edited by Paul Petrovic, Rowman and Littlefield, 2015, pp. 17-28.

Simonetti, Paolo. "Historical Fiction after 9/11: Thomas Pynchon's Against the Day." Modern Language Studies, vol. 41, no. 1, 2011, pp. 26-41.

St. Clair, Justin. "The Reality of Fiction in a Virtually Postmodern Metropolis: Jonathan Lethem's Chronic City and Thomas Pynchon's Bleeding Edge." The City Since 9/11: Literature, Film, Television, edited by Keith Wilhite, Fairleigh Dickinson University Press, 2016, pp. 89-105.

Solon, Olivia. "Is Our World a Simulation? Why Some Scientists Say It's More Likely Than Not." The Guardian, 11 October 2016, https://www.theguardian.c om/technology/2016/oct/11/simulated-world-elon-musk-the-matrix.

Westphal, Bertrand. Geocriticism: Real and Fictional Spaces. Palgrave, 2011. 